\title{
Thermal performance ensuring for enclosing structures
}

\author{
Inna Egorochkina*, Irina Serebryanaya, Elena Shlyakhova, Alena Buzanova, and Zaurbek \\ Bakaev
}

Don State Technical University, 344000, Rostov-on-Don, Russia

\begin{abstract}
The problem of thermal energy increased consumption for heating residential buildings is identified. The solution of this issue is to increase the thermal characteristics of enclosing wall structures by insulating them with effective heat-insulating materials. The results of a comparative analysis on the quality parameters of building materials used for building envelopes insulation are presented. The data of facade systems multilayer structures models' thermal engineering calculation are given. The recommendations for ensuring safety and energy efficiency parameters during construction and installation work on the enclosing structures' insulation are presented.
\end{abstract}

\section{Introduction}

The strategic objectives of the Russian Federation development include improving the activities of the fuel and energy complex organizations, which have a significant impact on improving living conditions of the population and reducing the negative impact of energy facilities on the climate and the environment [1].

The main measures that ensure the energy conservation and energy efficiency improvement problems solution include a ban on the production and use of energy inefficient machinery, equipment, technological processes, as well as buildings and structures $[1,2]$.

Comparison of the energy consumption types shows that about $40 \%$ of the total energy consumption is spent on housing and communal services [2]. The task of reducing energy consumption for heating residential buildings is becoming highly relevant, especially for the old housing stock, the maintenance of which is entrusted to residents [3].

The problem of reducing energy consumption should be addressed in a comprehensive manner [4]. The solutions to improve thermal performance of enclosing structures, the use of heating systems with controlled thermal modes with a competent approach, will ensure a high level of safety and comfort for human life.

In energy saving, great importance is attached to minimizing heat losses through the enclosing structures [5].

Recently, the cases of residents' claims of panel residential buildings for unsatisfactory temperature and humidity conditions of the air environment of living rooms have become

*Corresponding author: arin77@bk.ru 
more frequent. In the complaints, there is high humidity and low air temperature in living rooms, the appearance of condensation and traces of mold on the walls' inner surfaces.

The inspections carried out within the framework of the construction and technical expertise made it possible to establish the microclimate parameters inconsistency of the premises with the established standards, which is due to the operation of wall structures that do not meet the requirements for energy efficiency.

Insulation of external walls with effective heat-insulating materials will provide the required level of thermal resistance and restore normal microclimate parameters in residential premises.

Currently, various building materials and technologies are used to ensure the regulatory parameters of the residential buildings' energy efficiency [6-8].

The simplest and most common is the insulation of walls inside the premises. The method is simple, convenient, economical and available to ordinary consumers for the independent installation of an internal insulation layer. However, in some cases, such insulation is ineffective, especially for leeward end walls, and after several years of operation, the effectiveness of thermal protection decreases. Such a system does not contribute to the removal of the dew point outside the wall structure, and it is just that most often condensation appears inside the insulation.

The correct solution is outdoor insulation. Experts always recommend to insulate the walls with a "frosty coat". External insulation is carried out by plastering walls, using multilayer structures with internal insulation, using hinged ventilated facades (HVF). The main elements of HVF are effective insulation, moisture and windscreen, facing plates.

An assortment of modern building materials for the device HVF quite saturated [7, 8]. Certain HVF operating experience has been accumulated. A number of problems were identified, associated with both the quality of the building materials used and the design and installation features of the system, and with the subsequent operation of the building [9]. It is obvious that improving the thermal protection of enclosing structures lies in the competent choice of building materials and competent installation of the facade system.

\section{Targets and goals}

This research work is devoted to the problem of improving the thermo-technical parameters of the wall structures quality in order to ensure the energy efficiency of residential buildings, which is a mandatory requirement for buildings and structures in accordance with the Federal Law of the Russian Federation No. 384 "On the safety of buildings and structures".

The purpose of the research work is to establish the thermal characteristics of the enclosing structures of a residential building and the development of design solutions that ensure the creation of favorable climatic and sanitary and hygienic conditions in premises.

The research work object is the exterior wall panels of a residential building, which was put into operation in 2019 .

The subject of the research is the thermal characteristics of the external wall panels of a residential building before and after insulation.

In order to establish the compliance of the thermal technical characteristics of the building envelope with the regulatory requirements, the parameters for the quantitative assessment of energy efficiency were determined:

- resistance to heat transfer of building envelopes;

- resistance to air permeability of enclosing structures;

- resistance to vapor permeability of enclosing structures;

- temperature and humidity inside the dwelling;

- outdoor temperature and relative humidity; 
- the temperature difference on the inner surface of the enclosing structures and the air temperature inside the room;

- other characteristics for assessing the microclimate of a dwelling.

\section{Materials and research methods}

Full-scale and laboratory measurements were carried out according to standard methods using modern measuring instruments.

Measurement and assessment of the thermal performance of the enclosing structures was carried out according to the GOST 25380 method. Temperature measurements were carried out in accordance with GOST 12.1.005. The calculation of the required resistance to heat transfer of the enclosing structures was carried out according to the method $\mathrm{BC}$ 50.13330.2021.

The reduced resistance to heat transfer of the enclosing structures insulated by the hinged ventilated facade system was calculated in accordance with the methodology BC 345.1325800 .2017 taking into account the redistribution of heat in the metal frames and brackets' installation nodes.

The general scheme for measuring the heat flux density is shown in Figure 1.

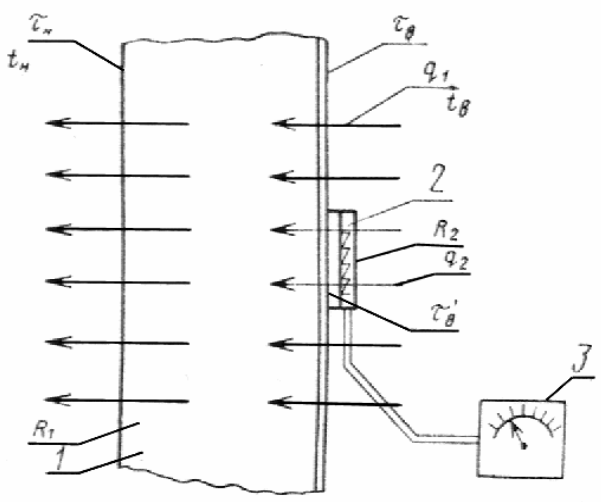

a)

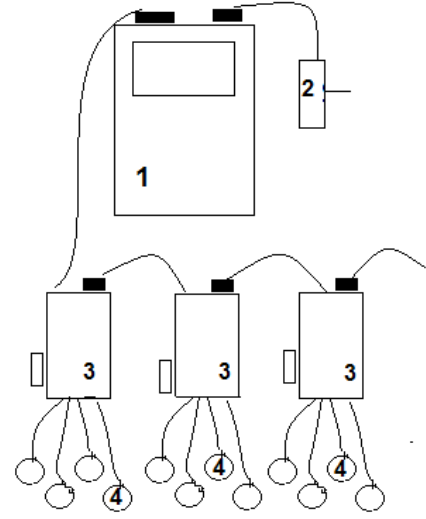

b)

Fig. 1. Measurement and evaluation of the wall structures' thermal performance: a) heat flux density measurement scheme: 1 - external wall panel; 2 - heat flow converter; 3 - digital voltammeter B7-21; b) equipment: 1- electronic unit of the device ITP-MG4.03/10(I) «Stream» (IPTP10_MG4); 2network adapter; 3 - programmable ten-channel module; 4 - heat flow sensors (platinum resistance temperature sensors).

The measurements were carried out on full-scale wall structures of a residential building and on the models of wall structures insulated with effective heat-insulating materials (Table 1).

\section{Experimental part}

In order to select the effective heat-insulating materials and the optimal scheme of insulation of wall structures in laboratory conditions, the density of heat fluxes passing through the wall structure model was determined for checking the constructive solution effectiveness of insulation and further implementation at the construction site. 
Table 1. Full-scale and model samples of wall structures

\begin{tabular}{|c|c|c|c|}
\hline $\begin{array}{c}\text { Properti } \\
\text { es }\end{array}$ & Sample № 1 & Sample № 2 & Sample № 3 \\
\hline Scheme & $\begin{array}{l}\text { Ain } \\
\text { Expanded clay } \\
\text { concrete exterior } \\
\text { wall panel }\end{array}$ & Warm "Facade model" & $\begin{array}{l}\text { Model "Hinged } \\
\text { ventilated facade" }\end{array}$ \\
\hline Scheme & $\begin{array}{l}\text { Expanded clay } \\
\text { gravel aggregate } \\
\text { concrete }\end{array}$ & $\begin{array}{l}\text { Substrate concrete / brick, } \\
\text { Adhesive for thermal } \\
\text { insulation, thermal } \\
\text { insulation material, } \\
\text { reinforcing adhesive, primer } \\
\text { for plaster, decorative } \\
\text { plaster, paint layer }\end{array}$ & $\begin{array}{l}\text { Concrete / brick base, } \\
\text { supporting subsystem } \\
\text { of metal profiles, } \\
\text { thermal insulation } \\
\text { material, siding, } \\
\text { porcelain stoneware, } \\
\text { composite panels }\end{array}$ \\
\hline \begin{tabular}{|c|} 
Thickne \\
ss
\end{tabular} & $140 \mathrm{~mm}$ & $180(200) \mathrm{mm}$ & $200(220) \mathrm{mm}$ \\
\hline $\begin{array}{c}\text { Thermal } \\
\text { conducti } \\
\text { vity }\end{array}$ & $0,8-1,2 \mathrm{~W} / \mathrm{m}^{2}{ }^{\circ} \mathrm{C}$ & $0,3-0,5 \mathrm{~W} / \mathrm{m}^{2}{ }^{\circ} \mathrm{C}$ & $0,25-0,3 \mathrm{~W} / \mathrm{m}^{2}{ }^{\circ} \mathrm{C}$ \\
\hline
\end{tabular}

The measurements were taken at an ambient temperature $(-4 \pm 0,1)^{0} \mathrm{C}$. The surface temperature of the enclosing structure outside is $(-6 \pm 0,1)^{0} \mathrm{C}$. Room air temperature is $(+15 \pm 0,1)^{0} \mathrm{C}$. Internal surface temperature of the enclosing structure is $(+12 \pm 0,1)^{0} \mathrm{C}$.

Seven control sites were selected on the enclosing structure with a surface layer of one material (expanded clay concrete), remote from heating devices.

Evaluation of the enclosing wall structures' insulation effectiveness was carried out on the specially made external walls' models, insulated according to the "Warm facade" and "Hinged ventilated facade" schemes in a testing laboratory under the conditions identical to the control tests at a full-scale object in a residential building.

The measurement results of the control sample No. 1 are presented in Table 2 .

Table 2. Thermal characteristics of external walls surveyed object (residential building)

\begin{tabular}{|c|c|c|c|c|c|c|c|c|c|}
\hline \multirow{3}{*}{$\begin{array}{l}\text { Plot } \\
\text { no. }\end{array}$} & \multicolumn{6}{|c|}{ Instrument indications } & \multirow{3}{*}{$\begin{array}{c}\text { Thermal } \\
\text { conductivity, } \\
\mathrm{W} / \mathrm{m}^{2}{ }^{\circ} \mathrm{C}\end{array}$} & \multirow{2}{*}{\multicolumn{2}{|c|}{$\begin{array}{c}\text { Thermal resistance, } \\
\mathrm{m}^{2} \cdot{ }^{\circ} \mathrm{C} / \mathrm{W}\end{array}$}} \\
\hline & \multicolumn{5}{|c|}{ Measurement number } & \multirow{2}{*}{$\begin{array}{c}\text { Averag } \\
\mathrm{e}\end{array}$} & & & \\
\hline & 1 & 2 & 3 & 4 & 5 & & & actual & normal \\
\hline 1 & 33 & 34 & 34 & 31 & 33 & 33.0 & 0.64 & 0.71 & \multirow{7}{*}{2.57} \\
\hline 2 & 50 & 50 & 52 & 53 & 52 & 51.4 & 0.98 & 1.14 & \\
\hline 3 & 30 & 32 & 32 & 33 & 32 & 31.8 & 0.60 & 0.76 & \\
\hline 4 & 29 & 31 & 29 & 30 & 30 & 29.8 & 0.56 & 0.73 & \\
\hline 5 & 30 & 30 & 31 & 30 & 30 & 30.2 & 0.57 & 0.73 & \\
\hline 6 & 29 & 32 & 32 & 33 & 32 & 31.6 & 0.60 & 0.76 & \\
\hline 7 & 36 & 36 & 34 & 36 & 34 & 35.2 & 0.67 & 0.83 & \\
\hline
\end{tabular}


The inspected wall structures do not meet the regulatory requirements to ensure a safe level of the enclosing structures' thermal resistance, which is the reason for the building energy efficiency unsatisfactory level.

The presence of local defects (high humidity in certain areas, violation of the assembly seams tightness, surface flaking, etc.) are the reason for the decrease in comfort criteria and increased consumption of thermal energy for the building heating. Ensuring effective thermal insulation of wall structures will significantly increase the energy efficiency class.

An integrated approach is required to solve the identified problem:

- it is necessary to ensure the required thermal resistance of external enclosing structures by insulating them with effective heat-insulating materials;

- restore the joints' tightness;

- ensure the heating system and ventilation operation in accordance with regulatory requirements.

The choice of thermal insulation materials to improve the thermal performance of enclosing structures is based on taking into account the most important physical and mechanical, operational, technological and environmental parameters [10].

When choosing a structural scheme of enclosing structures, the coefficient of heat engineering uniformity and the durability factor of the materials used must be taken into account.

The analysis of construction-technical and physical-mechanical indicators of the used heaters is carried out. The analysis results are presented in Table 3.

The comparative analysis of building materials used for wall insulation showed that the most promising and durable are the heat-insulating plates made of basalt (stone) wool and expanded extruded polystyrene. It is equally important to take into account the multidurability factor of the materials used. There are known cases of the facade system premature failure, due to the loss of the thermal insulation properties, violation of the facing panels' protective functions, deformation and corrosion of the frame, destruction of the facing plates' fasteners [11].

Table 3. Construction and technical indicators of heaters for walls

\begin{tabular}{|l|c|c|c|c|}
\hline \multicolumn{1}{|c|}{ Insulation type } & $\begin{array}{c}\text { Density, } \\
\mathrm{kg} / \mathrm{m}^{3}\end{array}$ & $\begin{array}{c}\text { Thermal } \\
\text { conductivity, } \\
\mathrm{W} / \mathrm{m}^{2}{ }^{\circ} \mathrm{C}\end{array}$ & $\begin{array}{c}\text { Combust } \\
\text { ibleness } \\
\text { group }\end{array}$ & $\begin{array}{c}\text { Vapor } \\
\text { permeability } \\
\mathrm{MG} /(\mathrm{m} \cdot \mathrm{h} \cdot \mathrm{Pa})\end{array}$ \\
\hline $\begin{array}{l}\text { Glass wool mineral wool } \\
\text { ("mineral wool") }\end{array}$ & $10-50$ & $0.029-0.052$ & $\mathrm{C} 1-\mathrm{NC}$ & $0.5-0.6$ \\
\hline $\begin{array}{l}\text { Basalt mineral wool (stone } \\
\text { wool) }\end{array}$ & $30-220$ & $0.032-0.048$ & $\mathrm{NC}$ & $0.25-0.35$ \\
\hline $\begin{array}{l}\text { Expanded polystyrene (PAU, } \\
\text { PS, EPS) ("Foam plastics") }\end{array}$ & $25-35$ & $0.030-0.045$ & $\mathrm{C} 1-\mathrm{C} 4$ & 0.05 \\
\hline $\begin{array}{l}\text { Extruded polystyrene foam } \\
\text { (XPS) }\end{array}$ & $25-45$ & $0.029-0.034$ & $\mathrm{C} 3-\mathrm{C} 4$ & 0.013 \\
\hline Expanded clay & $400-800$ & $0.07-0.19$ & $\mathrm{NC}$ & 0.21 \\
\hline Aerated concrete D300 & 300 & $0.072-0.088$ & $\mathrm{NC}$ & $0.23-0.26$ \\
\hline \multicolumn{7}{|l|}{ Comparison with bricks } & $\mathrm{NC}$ & 0.11 \\
\hline Solid brick & 0.56 & 1800 & $\mathrm{NC}$ & 0.17 \\
\hline Hollow brick & 0.36 & 1200 &
\end{tabular}

The factors that determine the operational safety, reliability and durability of ventilated facades are analyzed (Table 4). 
Table 4. Analysis of factors affecting the safety parameters and quality of the HVF system

\begin{tabular}{|l|l|l|}
\hline $\begin{array}{l}\text { Quality } \\
\text { parameters }\end{array}$ & \multicolumn{1}{|c|}{ The main risks } & \multicolumn{1}{c|}{ Influencing factors } \\
\hline \multirow{5}{*}{ Reliability } & $\begin{array}{l}\text { - risk of mechanical } \\
\text { collapse, destruction of } \\
\text { the HVF structure; } \\
\text { - a building freezing; } \\
\text { - loss of the aesthetic } \\
\text { appearance of the facade } \\
\text { under the external loads } \\
\text { influence }\end{array}$ & $\begin{array}{l}\text { - the type and strength of the wall material } \\
\text { (e.g. aerated concrete); } \\
\text { - poor quality or incorrectly selected } \\
\text { fasteners; } \\
\text { - insufficient number of rivets or the use of } \\
\text { rivets that are not permissible for fixing } \\
\text { porcelain stoneware; } \\
\text { - unauthorized installation of attachments or } \\
\text { additional structures (advertising) on the } \\
\text { building facade }\end{array}$ \\
\hline \multirow{5}{*}{ Durability } & $\begin{array}{l}\text { - structural corrosion; } \\
\text { - Loosening of fasteners } \\
\text { - destruction of external } \\
\text { cladding (from ceramic } \\
\text { granite and natural stone) } \\
\text { - loss of thermal } \\
\text { insulation of the facade }\end{array}$ & $\begin{array}{l}\text { - electrochemical corrosion as a result of the } \\
\text { use of dissimilar metals in structural } \\
\text { elements (for example, aluminum and } \\
\text { galvanized steel); } \\
\text { - dynamic alternating load caused by wind, } \\
\text { temperature and humidity influences; } \\
\text { - insufficient moisture absorption of } \\
\text { porcelain stoneware or natural stone }\end{array}$ \\
\hline
\end{tabular}

For the adopted technical solution of the HVF device, to confirm compliance with all thermal properties, the calculation of the thermal parameters of the outer wall was carried out using the proposed system. The coefficient of thermal engineering homogeneity of the structure has been determined. The calculation results are presented in Table 5.

Ttable 5. HVF thermal characteristics

\begin{tabular}{|c|c|c|c|c|c|}
\hline \multirow{2}{*}{$\begin{array}{c}\text { Structure } \\
\text { layers } \\
\text { facade }\end{array}$} & $\begin{array}{c}\text { Thickness } \\
\delta, \mathrm{m}\end{array}$ & $\begin{array}{c}\text { Density } \gamma, \\
\mathrm{kg} / \mathrm{m}^{3}\end{array}$ & $\begin{array}{c}\text { Thermal parameters } \\
\text { permeability, } \\
\begin{array}{c}\mu, \\
\mathrm{MG} / \mathrm{m} \cdot \mathrm{h} \cdot \mathrm{Pa})\end{array}\end{array}$ & $\begin{array}{c}\text { Thermal } \\
\text { conductivity } \\
\lambda, \mathrm{W} /(\mathrm{m} \cdot \mathrm{K})\end{array}$ & $\begin{array}{c}\text { Resistance } \\
\text { heat transfer layer } \\
\mathrm{R}_{0}{ }^{\mathrm{con}}=\mathrm{b} / \lambda, \\
\mathrm{m}^{2} \mathrm{C} / \mathrm{W}\end{array}$ \\
\hline $\begin{array}{c}\text { Expanded } \\
\text { clay } \\
\text { concrete }\end{array}$ & 0,14 & 2000 & 0.12 & 0.76 & $\mathrm{R} 1=0.82$ \\
\hline $\begin{array}{c}\text { Insulation } \\
\text { Rockwool }\end{array}$ & 0.12 & 80 & 0.32 & 0.038 & $\mathrm{R} 2=3.158$ \\
\hline Air gap & 0.03 & - & - & - & $\mathrm{R} 3=0.16$ \\
\hline HF & - & - & - & - & $\begin{array}{c}\Sigma \mathrm{R}=\mathrm{R} 1+\mathrm{R} 2+\mathrm{R} 3 \\
=4.199\end{array}$ \\
\hline
\end{tabular}

The calculations carried out in accordance with the BC 23-101, BC 50.13330 recommendations and methods made it possible to ascertain the fulfillment of the conditions for energy saving of enclosing structures insulated with a hinged ventilated facade.

\section{Conclusion}

The measurements and calculations give a possibility to single out several factors, taking 
into account which of them will increase the buildings walls thermal protection efficiency:

- the correct choice of the facade system elements, which consists in the optimal ratio of indicators of physical and mechanical properties;

- taking into account the heat engineering homogeneity and durability of a multilayer structure materials;

- a method of constructing a frame that perceives mechanical and dynamic effects of power, atmospheric and wind loads;

- control of the ventilated space high-speed flow by means of the device of dividing partitions and cutoffs;

- the use of windproof insulation coatings to prevent destruction of the cladding surface layers;

- compliance with the technology for the facade system construction, and the corresponding clear control of installation work.

The research work presents proposals for the insulation of enclosing structures with a hinged ventilated facade. The calculations to optimize the technical solutions for the device of a hinged ventilated facade due to a thermal protection device using mineral wool insulation with high strength characteristics made it possible to ascertain the fulfillment of the conditions for the enclosing structures' energy saving.

\section{References}

1. Government Order of the Russian Federation of June 9, 2020. No. 1523-r. On the energy strategy of the Russian Federation for the period up to 2035 [Electronic resource]: http://www.consultant.ru

2. S.G. Sheina, E.V. Martynova, K.I. Golotina, Engineering Journal of Don 2, (2013) ivdon.ru/magazine/archive/n2y2013/70

3. A.A. Afanasyeva, Reconstruction of residential buildings. Part 1: Technologies for restoring the operational reliability of residential buildings: a tutorial (JSC "CPP", M., 2008)

4. I.O. Egorochkina, E.Yu. Romanenko, A.V. Buzanova, I.A. Dokhlenko, Engineering Journal of Don 1, 207-215 (2021) www.ivdon.ru/ru/magazine/archive/n1y2021/6774

5. S. Sheina, P. Fedyaeva, E. Chulkova, T. Pavlukova, Belousova O. Ecological aspects of energy conservation programmes (Internationaler Kongress\& Fachmesse EUROECO: Program Abstracts, Hannover, 2010)

6. K. Rzepat, W. Wons, M. Reben, Building ceramics with improved thermal insulation parameters, 1st International Conference on the Sustainable Energy and Environment Development (seed 2016). E3S Web of Conferences 10, UNSP 0008. (2016) DOI: $10.1051 / \mathrm{e} 3$ sconf $/ 20161000082$

7. I.A. Serebryanaya, I.O. Egorochkina, E.A. Shlyakhova, A.A. Matrosov, D.S. Serebryanaya, Integrated construction and technical structural analysis of the industrial buildings, In: IOP Conference Series: Materials Science and Engineering Construction and Architecture: Theory and Practice of Innovative Development" (CATPID-2020) 022071 (2020) DOI: 10.1088/1757-899X/913/2/022071

8. S.G. Abramyan, A.A. Kotlyarevsky, Naukovedenie 9 (6), (2017) URL: naukovedenie.ru/PDF/40TVN617.pdf

9. I.R. Baikov, O.V. Smorodova, S.V. Kitaev, Nanotechnologies in construction Scientific Internet-Journal 10 (5), 106-121 (2018) DOI: 10.15828/2075-8545-2018-105-106-121 
10. I.O., Egorochkina, I.A. Serebryanaya, V.A. Khrameeva, On the issue of assessing the operational reliability and durability of insulated facade surfaces, In the book: Construction - 2015: modern problems of construction: materials of the international scientific and practical conference 537-539 (2015)

11. A.E. Rusanov, S.G. Golovnev, Bulletin of the South Ural State University. Construction and Architecture Series 2, 92-95 (2014) 